\title{
Congruence Index Between Personal and Organizational Values: A Proposed Model for Calculation
}

\author{
FREDERICO MACIEL MOREIRA \\ University of Brasíilia Brasil. \\ SONIA RESENDE \\ University of Brasíilia Brasil. \\ Email: resendesonia70@gmail.com \\ ELAINE RABELO NEIVA \\ University of Brasíilia Brasil.
}

\begin{abstract}
The development of values research, associated with a growing concern of organizational culture issues, provided a fertile field for studies directed to the application of theory to practice. In this scenario, the concept of fit $P-O$ arises in order to obtain more objective information about the congruence between employee and organization, both for diagnosis and proposition of solutions. With a representative sample of a Brazilian public organization $(n=457)$, the Congruence Index $(C I)$ is proposed, based on vector calculations, which considers both the difference and the intensity of the values profiles. The various methods of calculating congruence performed have shown that the results can be complex and of difficult significance. The presented model is more suitable to a global measure of fit, considering spatial theoretical models. The organization studied had $C I=16 \%$, which is considered a low value of congruence.

Keywords: P-O Fit, Congruence, Personal Values, Organizational Values, Fit Index.
\end{abstract}

\section{Introduction}

In recent decades, the pursuit of organizational performance effectiveness has directed researchers and practitioners toward the concept of congruence between personal values and organizational values (Chatman 1989, 1991; Cable \& Judge 1996; Westerman \& Cyr 2004). Value congruence is perceived as a positive phenomenon, considering that employees not only support organizational values, but also protect, promote and adhere to them (Kristof-Brown, 1999; Hoffman \& Woehr, 2006). The congruence of personal and organizational values can be used both in selection to attract and retain employees, as well as in development and management programs to ensure targeted and desired behavior of members of the organization.

Value congruence means that the worker not only agrees with the organization's values, but also maintains and values them (Vveinhardt \& Gulbovaite, 2016). The central point of the concept of congruence is that neither traits (or values) nor the situation determine the individual's behavior but the interaction between them (Ostroff \& Schulte, 2007; Caldwell, Chatman \& O'Reilly, 2007). "When employees and organizations live their values in the same degree, there is an impact on organizational commitment and therefore on organizational effectiveness," stress Malbašic, Mas-Machuca \& Marimon (2018, p.101). For Chatman (1991), congruence increases with time of socialization in the organization due to changes in individual values. 
The literature on value congruence is fragmented due to different methodological treatments and theoretical perspectives (Bao, Dolan \& Tzafrir, 2012). Research shows that the value congruence dilemma is: (a) generally examined in individual aspects; (b) there are no complex models of congruence of personal and organizational values; and (c) most models include an insufficient number of elements of congruence of personal and organizational values. Vveinhardt and Gulbovaite (2014) also point out that most instruments applied in recent research were designed a long time ago, without updating. These instruments are: Survey of Work Values - SWV (Wollack, Goodale, Wijting, Smith \& Feishman, 1971), Meaning and value of work scale - MVW (Kazanas, 1978), Organizational Culture Profile - OCP (O'Reilly, Chatman \& Caldwell, 1991), Comparative Emphasis Scale - CES (Meglino \& Ravlin, 1998), Organizational Values Congruence Scale - OVCS (Enz, 1988), Schwartz Value Survey - SVS (Schwartz, 2005b), Portrait Value Questionnaire - PVQ (Schwartz, 2005a).

Another issue is that value congruence only has direct questions to the employee to assess how much their personal values match their organization's values (Westwood \& Posner, 1997; Cable \& DeRue, 2002; Siegall \& McDonald, 2004; Vveinhardt \& Gulbovaite, 2014). For the evaluation and calculation of fit, there is a wide range of methods, with no convergence around any of them. Many studies use only the visual comparison of personal and organizational values, by overlapping geometric figures or radar charts, without calculating a congruence score (See De Clerq, 2006; Panahí, Moezzi, Preece \& Zacaria, 2016). There is a gap, also, in measuring the force of congruence between values. As Vveinhardt \& Gulbovaite (2014, p. 138) point out: “(...) the evaluation of congruence of personal and organizational values does not reveal the deep points of contact of specific values". It was also not found in the literature a calculation formula suitable to Schwartz's (1994) circular model of personal values and its possible adaptations, such as the IPVO for organizational values.

For these reasons, paper aims to propose a Congruence Index (CI), as an alternative calculation model to evaluate the congruence between personal values and organizational values, bringing evidence of validity for its use. This model is based on a vector analysis, in order to match Schwartz's circular model (1994).

\section{Individual and Organizational Values}

Human values can be defined as (a) beliefs linked to emotion intrinsically that generate positive and negative feelings, (b) principles that guide people to act in various social contexts, (c) a guide the selection and evaluation of actions, policies, people and events (d) a criteria for judgments that transcend specific situations and actions, and (e) are ordered by importance, forming a system of axiological priorities (Torres, Schwartz \& Nascimento, 2016, p .342). Organizational values are the central element of the organizational culture (Hofstede, 1980). They determine models of desired behaviors and create moral basis for goals and activities (Ivanova \& Kokina, 2016). Based on Schwartz and Bilsky's universal model of personal values (1990) south american scholars made adaptations for the organizational level (Tamayo \& Gondim, 1996; Tamayo, Mendes \& Paz, 2000; Oliveira \& Tamayo, 2004; Tamayo, 2005). These authors consider that while personal values express the goals of individuals, organizational values express the goals of the organization. Thus, personal and organizational values represent solid systems that allow us to predict the functioning of the organization and the behavior of individuals. Oliveira and Tamayo (2004) developed the Inventory of Profiles of Organizational Values (IPVO), in the same logic of Schwartz's $\mathrm{PVQ}$, with 48 descriptions of work situations and the degree of respondents. Even starting from a common theoretical basis, personal values and Organizational values are distinct constructs and measuring value congruence requires some operations that were only possible with the evolution of PO fitting studies.

\section{P-O Fit Studies}

Congruence when occurs a 'fit' between the individual and the organization, and may encompass a wide range of types, such as Person-Work, Person-Person, Person-Organization, Person-Group, etc., determining the type of analysis. to be carried out and how the construct will be operationalized (Kristof, 1996; Harrison 
\& Sin, 2007; Ostroff \& Schulte, 2007). Measuring congruence by comparing personal and organizational values has been the most widely used in the literature (Kristof-Brown \& Jansen, 2007). Congruence can occur by similarity or complementarity, as Muchinsky and Monahan (1987) explain.

The earliest studies actually referred to as fitting go back to the 1980s and 1990s (Muchinsky \& Monahan, 1987; Schneider, 1987b; Caplan, 1987; Chatman, 1989), most of which used the concept of values. Research in the 1990s and 2000s looks at how value congruence can affect other organizational variables. Recent studies show the impact of congruence between personal and organizational values on organizational success and effectiveness, in bringing together all members of an organization (Vveinhardt \& Gulbovaite, 2013; Titov \& Umarova, 2017). Value Congruence has been considered the most appropriate predictor of important variables for organizations, such as Organizational Commitment (Caldwell, Chatman \& O'Reilly, 1990; O’Reilly et al, 1991; Kristof, 1996; Finegan, 2000; Westerman \& Cyr, 2004; Huang et al., 2005; Ostroff et al., 2005; Kristof-Brown, Zimmerman \& Johnson, 2005; Lawrence, 2006; Cennamo \& Gardner, 2008; Greguras \& Diefendorff, 2009; Chiang \& Birtch, 2010; Posner, 2010; Suar \& Khuntia, 2010; Leung \& Chaturvedi, 2011; Agarwal \& Sagar, 2012; Seggewiss, Boeggemann, Straatmann, Mueller \& Hattrup, 2018), Job Satisfaction (Chatman,1991; O'Reilly et al, 1991; Kristof, 1996; Lauver, Kristof-Brown, 2001; Tepeci \& Bartlett, 2002; Silverthorne, 2004; Verplanken, 2004; Westerman, \& Cyr, 2004; Siegall \& McDonald, 2004; Kristof-Brown, Zimmerman \& Johnson, 2005; Huang et al., 2005; Ostroff et al, 2005; Lawrence, 2006; Cennamo \& Gardner, 2008; Edwards \& Cable (2009); Greguras \& Diefendorff (2009); Chiang \& Birtch (2010); Kallas et al., 2010; Posner, 2010); Suar \& Khuntia, 2010); Leung \& Chaturvedi, 2011; Spanjol, Tam \& Tam, 2015; Panahi, Moezzi, Preece \& Zakaria, 2016; Hudson, Bryson \& Michelotti, 2017), motivation at work (Kristof, 1996; Lawrence, 2006; Posner, 2010; Ren, 2010; Kim, 2012; Ren e Hamann, 2015), Turnover and Intention to quit the job (Chatman, 1991; O'Reilly et al,1991; Kristof , 1996; Kristof-Brown, Zimmerman \& Johnson, 2005; Van Vianen, De Pater \& Van Dijk, 2007; Abzari, Kabiripour \& Saeidi, A.,2015; Rani \& Samuel, 2016); Hudson, Bryson \& Michelotti, 2017), Differences among Baby Boomers, Generation $X$ and Generation Y (Leiter, Jackson e Shaughnessy (2009)., Rani e Samuel (2016); Grobler \& Rensburg (2018).

\section{P-O Fit Calculation}

There are several ways to calculate the degree of fit P-O. The majority of adjustment studies have calculated value congruence using the arithmetic difference score method between perceived and ideal values, or use correlations between individual and organizational values (Tisak \& Smith, 1994; Cable \& Judge, 1996, 1997; O'Reilly et al., 1991).

Kristof's (1996) P-O value calculation method proposes the subtraction of personal values (P) from organizational values $(\mathrm{O})$ to create discrepancy scores. Positive results indicate that the organization does not meet personal values, and negative scores show that the values provided by the organization exceed personal values (Rani \& Samuel, 2016). Blau, Teachman and Euclidean distance indices can be used in case of categorical or ordinal variables (Harrison \& Sin, 2007) Standard deviation (SD), coefficient of variation $(\mathrm{CV})$, Gini index $(\mathrm{G})$ or Euclidean distance (DE) can also be used. The issue is that these methods gets lost the intensity

The use of polynomial equations is proposed by Edwards (1994, 2007), in the form of nonlinear multiple regression, containing measurements of both entities that are collapsed into a similarity index. However, many later studies have found that this way of calculating increases the variance explained (Kristof, 1996; Cable \& Judge, 1996; Goodman \& Svyantek, 1999; Ostroff \& Schulte, 2007).

In this paper, an alternative approach for intraindividual analysis and ipsative data testing will be suggested, which consists in a calculation method that uses closed-loop geometric means. 


\section{Method}

This study was conducted in a Brazilian public agency. The organization had a high turnover due to a large number of retirements and the appointment of new employees.

\section{Sample}

A total of 4,796 servers participated in the study. 853 were sworn in between 2010 and 2012, and the rest are old servers $(n=3,943)$. The organization has a strong concentration of male employees $(80 \%)$. The average age is 46.5 years $(\mathrm{SD}=10.9)$.

\section{Instruments}

To measure personal values was used the Portrait Value Questionnaire - PVQ (Schwartz, 2005b), with 40 items. The PVQ consists of short verbal descriptions of values, on which the following question should be answered: How much does this person look like you?

With a 6-point Likert scale, the score 6 should be considered for the item that most closely resembles the respondent (Schwartz, 2005b). In order to measure the perception of employees about organizational values, the IPVO Inventory Profile was used (Oliveira \& Tamayo, 2004). This questionnaire also uses a 6point Likert scale and consists of 48 brief value descriptions.

\section{Data Collection Procedure}

The instrument was available via an electronic form hosted on Lime Survey website, sent through an institutional e-mail to all. Respondents agreed to the Informed Consent Form.

\section{Data Analysis}

Factor analysis was performed using the Principal Axis Factoring (PAF) method with structured oblique rotation, according to Oliveira and Tamayo (2004). A KMO of 0.93 was obtained, and Bartlett's sphericity test rejected the null hypothesis ( $\mathrm{p}<0.001$ ). SPSS / PROXSCAL software was used, using Euclidean distance as the measure, with ordinal transformations and initial configuration according to Bilsky, Janik and Schwartz (2011) to validate the PVQ-21. The Spearman's $\rho$ correlations between the factors confirms the model.

\section{Results}

\section{Vector analysis congruence index}

Figure 1 shows the schematic profile of personal values and organizational values of the study sample, with a color gradient, from red to green, where red represents the least present value in the group and green, the most present value in the group.

To obtain the indicative parameter of the congruence between the values, a calculation method based on vector operations is proposed. For each value profile (personal and organizational) will be calculated resulting vectors, which will be compared. Differences in angles and intensities will determine the level of congruence between values. 

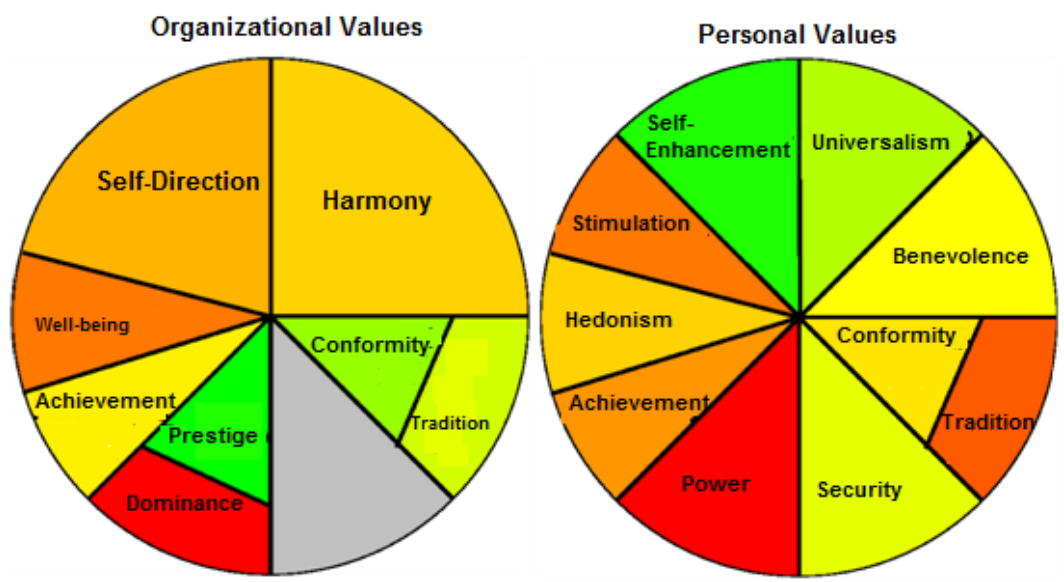

Figure 1. Profile of sample values based on Schwartz's (1994) circular model

All vectors are composed of direction, direction and intensity, being represented by $\mathrm{V}^{\rightarrow}(\mathrm{Vx}, \mathrm{Vy})$. That is,

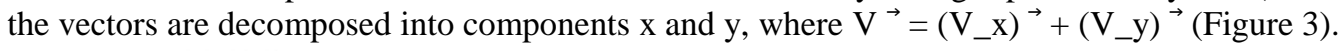

This decomposition allows you to perform the calculations to arrive at the resulting vector of each profile. In this model, the intensity will be obtained by the value attributed to the factors obtained by the mean. Direction and meaning were determined according to Schwartz's (1994) circular model.

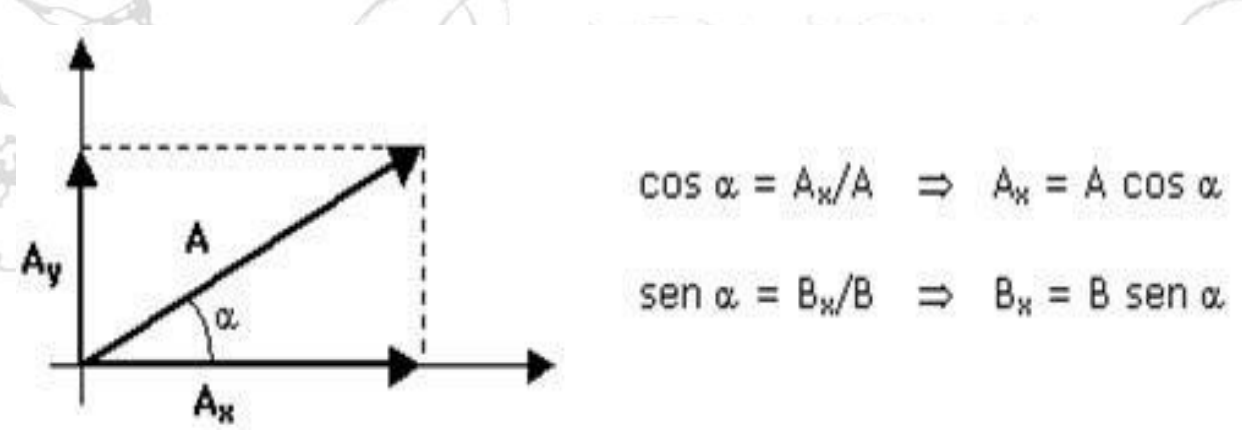

Figure 2. Example of vector decomposition

The vector calculation is based on the trigonometric circle, which all vectors have an intensity equal to 1 . The value of $\mathrm{Vx}$ is obtained by the calculation of $\cos \alpha$ and $\mathrm{Vy}$ by $\sin \alpha$. Thus, vectors can also be represented by $\mathrm{V}(\cos \alpha$, sen $\alpha)$ in the trigonometric circle. To obtain the resulting vector we need to multiply it by the factor intensity in the calculation. Therefore, $\mathrm{VR}=\mathrm{V}(\sin \alpha, \cos \alpha) \mathrm{x}$ Intensity (factor). The values are represented in the trigonometric circle, in 9 equal parts, 40o spaced, according to the distribution made by Bilsky et al. (2011). The angles of organizational values were stipulated by juxtaposing them to their personal values (following the logic of Figure 2). The angles obtained are shown in Table 2.

Once the direction and direction of the vectors were defined, the next step was to calculate the intensity of the vectors. The general means of the sample were used. The resulting vectors were obtained by summing $\mathrm{x} 1$ and $\mathrm{y} 1$, shown in Table 2 . 
Table 2 Angles and positions of the vectors in the trigonometric circle and resulting vectors

\begin{tabular}{|c|c|c|c|c|c|c|}
\hline Values & $\mathrm{X}=\cos \alpha$ & $=\operatorname{sen} \alpha$ & $\alpha$ & Fator. & $\mathrm{xl}$ & yl \\
\hline \multicolumn{7}{|l|}{ Personal Values } \\
\hline Universalism & 0,34 & 0,94 & 70 & 4,869 & 1,66 & 4,58 \\
\hline Benevolence: & 0,87 & 0,50 & 30 & 4,830 & 4,20 & 2,42 \\
\hline Tradition & 0,49 & $-0,09$ & 350 & 3,620 & 1,77 & $-0,33$ \\
\hline Conformity & 0,49 & $-0,09$ & 350 & 4,714 & 2,31 & $-0,42$ \\
\hline Security & 0,64 & $-0,77$ & 310 & 4,837 & 3,10 & $-3,72$ \\
\hline Power & 0,00 & $-1,00$ & 270 & 3,376 & 0,00 & $-3,38$ \\
\hline Achievement & $-0,64$ & $-0,77$ & 230 & 4,227 & $-2,71$ & $-3,25$ \\
\hline Hedonism & $-0,98$ & $-0,17$ & 190 & 4,267 & $-4,18$ & $-0,73$ \\
\hline Stimulation & $-0,87$ & 0,50 & 150 & 3,826 & $-3,33$ & 1,91 \\
\hline Self-Enhancement & $-0,34$ & 0,94 & 110 & 5,024 & $-1,71$ & 4,72 \\
\hline Personal Values General Index (Resultant vector) & & & & & 1,11 & 1,80 \\
\hline \multicolumn{7}{|l|}{ Organizational Values } \\
\hline Harmony & 0,64 & 0,77 & $\mathbf{5 0}$ & 4,406 & 2,82 & 3,39 \\
\hline Tradition & 0,49 & $-0,09$ & 350 & 4,697 & 2,30 & $-0,42$ \\
\hline Corformidade & 0,49 & $-0,09$ & 350 & 4,924 & 2,41 & $-0,44$ \\
\hline Prestige & 0,00 & $-0,50$ & 270 & 5,514 & 0,00 & $-2,76$ \\
\hline Dominance & 0,00 & $-0,50$ & 270 & 2,533 & 0,00 & $-1,27$ \\
\hline Achievement & $-0,64$ & $-0,77$ & 230 & 4,594 & $-2,94$ & $-3,54$ \\
\hline Well-being & $-0,98$ & $-0,17$ & 190 & 3,516 & $-3,45$ & $-0,60$ \\
\hline Self-Direction & $-0,64$ & 0,77 & 130 & 3,888 & $-2,49$ & 2,99 \\
\hline Organizational Values General Index (Resultant vector) & & & & & $-1,34$ & $-2,64$ \\
\hline
\end{tabular}

Note: Bilsky et al. (2011), Oliveira and Tamayo (2004).

In cases where two values occupied the same space, the intensity of the vectors was divided by 2 , so that there was no distortion in the calculation of the resulting vectors. To correctly represent the axiological priorities, the scale of the factors was inverted. The resulting vectors are represented in Figure 3.

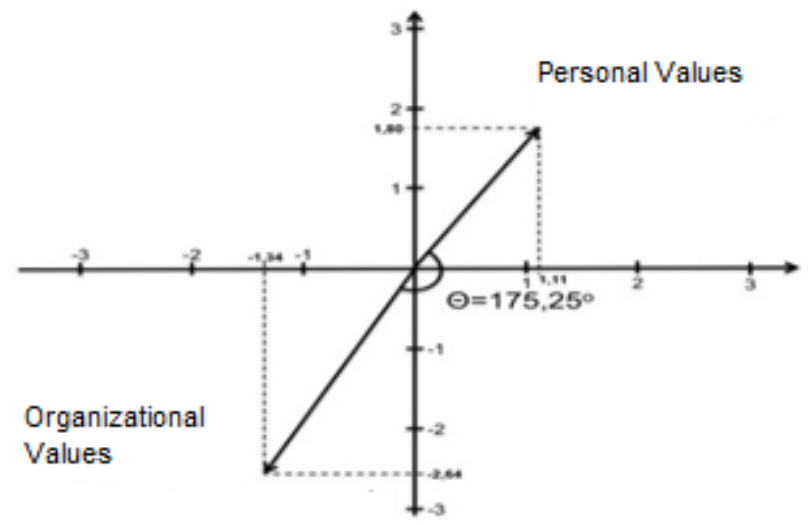

Figure 3. Vectors resulting from personal values and organizational values 
The resulting vector (VR) associated with organizational values is in a position between Achievement and Domain and Prestige $\left(230^{\circ}<\alpha<270^{\circ}\right)$ and the resulting vector associated with personal values is in a position between Universalism and Grace $\left(30^{\circ}<\alpha<70^{\circ}\right)$. The angle $\theta$ defines the main measure of the congruence index (CI). The calculation of $\theta$ is done according to the following steps. First, the hypotenuse $(\mathrm{H})$ value of the right triangle delimited by the resulting vectors is calculated. The value of $\mathrm{H}$ will give the intensity of the resulting vector. Calculation uses the Pythagorean theorem:

$$
H^{2}=x_{1}{ }^{2}+y_{1}{ }^{2}
$$

The hypotenuse of triangles associated with organizational values and personal values are represented respectively by HVO and HVP. In the sample studied, it was found that $\mathrm{HVO}=2.9606$ and $\mathrm{HVP}=2.1448$ Based on the values of $\mathrm{H}$ (HVO and HVP) and the components $\mathrm{Vx}$ and $\mathrm{Vy}(\mathrm{VxVO}, \mathrm{VxVP}, \mathrm{VyVO}$ and $\mathrm{VyVP})$, the values of $\operatorname{sen} \theta$ or $\cos \theta$ were calculated according to equations 2 and 3.

$$
\begin{aligned}
& \cos \cos \alpha=\frac{\text { Cateto adjacente }}{\text { Hipotenusa }} \\
& \alpha=\frac{\text { Cateto oposto }}{\text { Hipotenusa }}
\end{aligned}
$$

Considering the angles formed between the $\mathrm{x}$ axis and the resultant vector of personal values $(\theta \mathrm{VP})$, and between the $\mathrm{y}$ axis and the resultant vector of organizational values $(\theta \mathrm{VO})$, was obtain: $\theta_{\mathrm{VP}}=58,34^{\circ}$ e $\theta_{\mathrm{VO}}=$ $26,91^{\circ}$.

Since the resulting vectors are in opposite quadrants, the angle $\theta$ corresponds to the sum of $\theta \mathrm{VP}$ with $\theta \mathrm{VO}$ and 900 (equation 4).

$$
\theta\left(^{\circ}\right)=\theta_{\mathrm{VP}}+\theta_{\mathrm{VO}}+90^{\circ}
$$

Thus, for the sample analyzed, the value of $\theta$ is equal to $175.25^{\circ}$. A higher level of congruence occurs when $\theta$ tends to zero and the largest incongruence when tends to $180 \mathrm{o}$. Thus, the research data already indicate a high level of incongruity.

Another aspect that interferes with congruence is the intensity of the resulting vector. Opposite vectors with great intensity indicate a situation of extreme incongruity. Opposite vectors, in which one of them has much higher intensity than the other, indicate a situation of more moderate incongruity. Therefore, the proposal is to calculate the resulting vector of the resulting vectors (VRR). The VRR value is obtained by summing the resulting vectors: VR-VP and VR-VO, considering their respective intensity, direction and direction. In this study, VRR has as components Vx and Vy $-0.24 ; 0.84$, respectively, which results in HRR $=0.8736$.

In order to obtain values between zero and one, in a simplified way for comparison, it is proposed that HRR be divided by a value $\mathrm{k}$, according to the following assumptions. If VR-VO and VR-VP are in the same or adjacent quadrants: $\mathrm{k}=\mathrm{HVO}+\mathrm{HVP}$; if VR-VO and VR-VP are in opposite quadrants, $\mathrm{k}$ is the highest hypotenuse value between HVO and HVP. Thus, it is proposed that to calculate the Congruence Index (CI), consider the angular differences between the resulting vectors and their intensity differences, with the same weight, according to equation $5 . I C=0,5\left(1-\frac{\theta}{180}\right)+0,5\left(\frac{H_{R R}}{k}\right)$

Performing the calculations for the sample of this study has the $\mathrm{CI}=0.16$, which configures a low congruence index between personal values and organizational values, considering that this index ranges from 0 (zero) to 1 (one). 


\section{Discussion}

This study verified the application of the Congruence Index (CI), a method that uses vector operations to calculate values congruence, more appropriate to spatial models. The suggested method solves some of the difficulties presented in the calculation methods already used. This index gives, at the same time, the difference between personal and organizational values and also the intensity of these vectors. The IC result is a number between zero and one that shows a conceptually easy to understand and more robust result. The organization studied has $\mathrm{CI}=0.16$, which in graphic terms meant almost perfectly opposite vectors, representing a very small congruence. This index alerts the organization to further analysis of the situation in order to better understand the causes and improve the action plans.

\section{Conclusion}

The aim of this study was to present the development and validation of an innovative method for calculating the congruence between personal and organizational values. The vector calculation model is proposed to generate the Congruence Index (CI), with the great advantage of translating the compatibility of the values into numbers, allowing the analysis of the depth and the extent to which it occurs. Proposing a calculation method meets the lack of diagnostic instruments and objective measurement methods of value congruence, pointed by Vveinhardt and Gulbovaite (2014). The CI also fills a missing point, creating a concise link between the scholar literature and the organizational practices. The initial parameterization of the CI calculation was made from the schematic premise of Schwartz's model (1994) but can be used in other instruments. A limitation is that has been applied in a single organization, compromising the results'generalization. In future work, angles can be calculated from the dimensional model of your own data, leading to a more sophisticated and accurate calculation method.

\section{References}

Abzari, M., Kabiripour, V. \& Saeidi, A. (2015). The Effect of Business Ethical Values on Turnover Intention: Mediating Role of Person-organization Fit Dimensions. The Case of Iranian Teachers in Public School Academic Journal of Economic Studies, 1(1), 65-81.

Bao, Y., Dolan, S. \& Tzafrir, S. (2012). Value Congruence in Organizations: Literature Review, Theoretical Perspectives, and Future Directions. SSRN Electronic Journal.

Bilsky, W., Janik, M., \& Schwartz, S. H. (2011). The Structural Organization of Human Values-Evidence from Three Rounds of the European Social Survey (ESS). Journal of Cross-Cultural Psychology, 42(5), 759-776.

Cable, D. \& Judge, T. (1996). Person-organization fit, job choice decisions and organizational entry. Organizational Behavior and Human Decision Processes, 67(3), 294-311.

Cable, D. M. \& DeRue, D. S. (2002). The convergent and discriminant validity of subjective fit perceptions. Journal of Applied Psychology, 87, 875-884.

Caldwell, D. F. \& O'Reilly, C. A. (1990). Measuring person-job fit with a profile-comparison process. Journal of Applied Psychology, 75 (6), 648-657.

Caldwell, D. F., Chatman, J. A. \& O'Reilly, C. A. (2007). Profile comparison methods for assessing person-situation fit. In C. Ostroff \& T. A. Judge (Orgs.), Perspectives on organizational fit. (pp. 356361). New York: Psychology Press.

Caplan, R. D. (1987). Person-Environment fit theory and organizations: commensurate dimensions,time perspectives and mechanisms.Journ of Vocational Behavior,31,248-267.

Cennamo, L., \& Gardner, D. (2008). Generational differences in work values, outcomes and personorganisation values fit. Journal of Managerial Psychology, 23(8): 891-906.

Chatman, J.A. (1989). Improving interactional organizational research: A model of person-organization fit. Academy of Management Review, 14(3), 333-349.

Chatman, J.A. (1991). Matching people and organizations: selection and socialization in public accounting firms. Administrative Science Quarterly, 36 (3), 459-484. 
Chatman, J.A., Caldwell, D.F. \& O'Reilly, C.A.(1999). Managerial personality and performance:a semiidiographic approach. Journ. of Research in Personality,33,514-545.

Chiang, F. \& Birtch, T. (2010). Pay for performance and work attitudes: The mediating role of employeeorganization service value congruence. International Journal of Hospitality Management, 29(4), 632640.

Edwards, J. R., \& Cable, D. M. (2009). The value of value congruence. Journal of Applied Psychology, 94(3), 654-677.

Edwards, J.R. (1994). The study of congruence in organizational behavior research: critique and a proposed alternative. Organizat. Behav. and Human Decision Processes, 58, 51-100.

Edwards, J.R. (2007). Polynomial regression and response surface methodology. In C. Ostroff \& T. A. Judge (Orgs.), Perspectives on organizational fit. (pp. 361-372). New York: Psychology Press.

Enz, C.A. (1988). The role of value congruity in intraorganizational power. Administrative Science Quarterly, 33(2), 284-304.

Finegan, J. E.(2000). The impact of person and organizational values on organizational commitment. Journal of Occupational \& Organizational Psychology, 73(2): 149-169.

Goodman, S. A., \& Svyantek, D. J. (1999). Person-organization fit and contextual performance: Do shared values matter? Journal of Vocational Behavior, 55(2): 254-275.

Greguras, G.J., \& Diefendorff, J. M. (2009). Different fits satisfy different needs: Linking personenvironment fit to employee commitment and performance using self-determination theory. Journal of Applied Psychology, 94(2), 465-477.

Grobler, A. \& Rensburg, M.J. (2018). Organisational climate, person-organisation fit and turnover intention: a generational perspective within a South African Higher Education Institution. Studies in Higher Education, July.

Harrison, D.A. \& Sin, H.P. (2007). Heterogeneity ad Misfit. In C. Ostroff \& T. A. Judge (Orgs.), Perspectives on organizational fit (pp. 372-377). New York: Psychology Press.

Hoffman, B., \& Woehr, D. (2006). A quantitative review of the relationship between person-organization fit and behavioral outcomes. Journal of Vocational Behavior, 68(3), 389-399.

Hofstede, G.: 1980, Culture's Consequences: International Differences in Work-related Values. Beverly Hills, California: Sage Publications.

Hudson, S., Bryson, D. \& Michelotti, M. (2017). Individual'Assessment of Corporate Social Performance, Person-Organization Values and Goals Fit, Job Satisfaction and Turnover Intentions. Relations Industrielles/Industrial Relations, 72(2), 322-344.

Ivanova, M. \& Kokina, Y. (2016). The Analysis of Organizational Culture Values in Public Sectors in Latvia. Review of Innovation and Competitiveness, 2 (4).

Kazanas, H. (1978). Relationship of Job Satisfaction and Productivity to Work Values of Vocational Education Graduates. Journal of Vocational Behavior, 12 (2), 155-164.

Kim, S. (2012). Does person-organization fit matter in the public sector? Testing the mediating effect of person-organization fit in the relationship between public service motivation and work attitudes. Public Administration Review, 72 (6), 830-840.

Kristof, A.L. (1996). Person- organization fit: an integrative review of its conceptualizations, measurement, and implications. Personnel Psychology, 49 (1), 1-49.

Kristof-Brown, A.L. \& Jansen, K. J. (2007). Issues of Person-Organization fit. In C. Ostroff \& T. A. Judge (Orgs.), Perspectives on organizational fit. (pp. 123-153). New York: Psychology Press.

Kristof-Brown, A.L., Zimmerman, R.D. \& Johnson, E.C. (2005). Consequences of individuals' fit at work: a meta-analysis of person-job, person- organization, person- group, and person-supervisor fit. Personnel Psychology, 58 (2), 281-342.

Leiter, M. P., Jackson, N. J. \& Shaughnessy, K. (2009). Contrasting burnout, turnover intention, control, value congruence and knowledge sharing between Baby Boomers and Generation X. Journal of Nursing Management, 17(1): 100-109.

Leung, A. \& Chaturvedi, S. (2011). Linking the fits, fitting the links: Connecting different types of PO fit to attitudinal outcomes. Journal of Vocational Behavior, 79(2), 391-402. 
Malbašic, I., Mas-Machuca, M. \& Marimon, F. (2018). Through the Decreased Values Gap to Increased Organizational Effectiveness: The Mediating Role of Organizational Commitment. Journal of Human Values.

Meglino, B. M. \& Ravlin, E. C. (1998). Individual values in organizations: concepts, controversies, and research. Journal of Management, 24 (3), 351-389.

Muchinsky, P. M. \& Monahan, C.J. (1987). What is person-environment congruence? supplementary x complementary models of fit.Journ. of Vocational Behavior,31,268-277.

Oliveira, A.D.F. \& Tamayo, A. (2004). Inventário de perfis de valores organizacionais. Revista de Administração, São Paulo, 39 (2), 129-140.

O'Reilly, C., Chatman, J. A. \& Caldwell, D.F. (1991) People and organizational culture: a profile comparison approach to assessing Person-Organization fit. Academy of Management Journal, 34(3), 487-516.

Ostroff, C. \& Schulte, M. (2007). Multiple perspectives of fit in organizations across levels of analysis. In C. Ostroff \& T. A. Judge (Orgs.), Perspectives on organizational fit (pp. 3-69). New York: Psychology Press.

Ostroff, C. (2007). General methodological and design issues. In C. Ostroff \& T. A. Judge (Orgs.), Perspectives on organizational fit (pp. 352-356). New York: Psychology Press.

Panahi, B., Moezzi, E., Preece, C.N. \& Zakaria, W.N.W. (2016). Personal-organisational value conflicts and job satisfaction of internal construction stakeholders. Construction Economics and Building, 16(1), $1-17$.

Posner, B. (2010). Another Look at the Impact of Personal and Organizational Values Congruency. Journal of Business Ethics, 97(4), 535-541.

Rani, N. \& Samuel, A. (2016). A study on generational differences in work values and person-organization fit and its effect on turnover intention of Generation Y in India. Management Research Review, 39 (12), 1695-1719.

Ren, T. \& Hamann, D.J. (2015). Employee value congruence and job attitudes: the role of occupational status. Personnel Review, 44(4), 550-566.

Ren, T. (2010). Value Congruence as a Source of Intrinsic Motivation. Kyklos, 63, 94-109.

Risman, K.L., Erickson, R.J. \& Diefendorff, J.M. (2016). The impact of person-organiz.fit on nurse job satisfaction and patient care quality.Applied Nursing Research, 31,121-125.

Saraç, M., Efil, I. \& Eryilmaz, M. (2014). A study of the relationship between person- organization fit and employee creativity. Management Research Review, 37(5), 479-501.

Schneider, B. (1987b). The people make the place. Personnel Psychology, 40,437-453.

Schwartz, S. H. \& Bilsky, W. (1990). Toward a theory of the universal content and structure of values: extensions and cross-cultural replications. Journal of Personality and Social Psychology, 58(5), 878891.

Schwartz, S. H. (1994). Are there universal aspects in the structure and contents of human values? Journal of Social Issues, 50 (4), 19-45.

Schwartz, S. H. (2005a). Validade e aplicabilidade da teoria de valores. In A. Tamayo \& J.B. Porto. Valores e comportamento nas organizações (pp. 56-95). Petrópolis: Vozes.

Schwartz, S.H. (2005b). Valores humanos básicos: seu contexto e estrutura intercultural. In A. Tamayo \& J.B. Porto. Valores e comportamento nas organizações (pp. 21-55). Petrópolis: Vozes.

Seggewiss, B.J., Boeggemann, L.M., Straatmann, T., Mueller, K. \& Hattrup, K. (2018). Do Values and Value Congruence Both Predict Commitment? A Refined Multi-Target, Multi-Value Investigation into a Challenged Belief. Journal of Business and Psychology.

Siegall, M. \& McDonald, T. (2004). Person-organization value congruence, burnout and diversion of resources. Personnel Review, 33(3), 291-301.

Silverthorne, Colin. (2004). The impact of organizational culture and person-organization fit on organizational commitment and job satisfaction in Taiwan. (Author Abstract). Leadership \& Organization Development Journal, 25(7), 592-599.

Spanjol, J., Tam, L. \& Tam, V. (2015). Employer-Employee Congruence in Environmental Values: An Exploration of Effects on Job Satisfaction and Creativity. Journal of Business Ethics 130 (1), 117-130. 
Suar, D. \& Khuntia, R. (2010). Influence of Personal Values and Value Congruence on Unethical Practices and Work Behavior. Journal of Business Ethics, 97(3), 443-460.

Tamayo, A. \& Gondim, M.G.C. (1996). Escala de valores organizacionais. Revista de Administração da Universidade de São Paulo, 31 (2), 62-72.

Tamayo, A. (2005). Impacto dos valores pessoais e organizacionais sobre o comprometimento organizacional. In A. Tamayo \& J.B. Porto. Valores e comportamento nas organizações (pp. 160-186). Petrópolis: Vozes.

Tamayo, A., Mendes, A.M. \& Paz, M.G.T. (2000). Inventário de valores organizacionais. Estudos de Psicologia, 5 (2), 289-315.

Tepeci, M. \& Bartlett, A.L.B.(2002). The hospitality industry culture profile: a measure of individual values, organizational culture, and person-organization fit as predictors of job satisfaction and behavioral intentions. Int.Journal of Hospitality Managem., 21, 151-170.

Tisak, John, \& Smith, Carlla S. (1994). Defending and extending difference score methods. Journal of Management, 20(3), 675.

Titov, E. \& Umarova, L. (2017). Impact of Real and Propagated Values on Organisational Success. In Congruence of Personal and Organizational Values. IntechOpen.

Torres, Cláudio V., Schwartz, S. H. \& Nascimento, T. G. (2016). The Refined Theory of Values: Associations with behavior and evidences of discriminative and predictive validity. Psicologia USP, 27(2), 341-357.

Van Vianen, A., De Pater, I. E., \& Van Dijk, F. (2007). Work value fit and turnover intention: same-source or different-source fit. Journal of Managerial Psychology, 22(2), 188-202.

Verplanken, B. (2004). Value congruence and job satisfaction among nurses: A human relations perspective. International Journal of Nursing Studies, 41(6): 599-605.

Vveinhardt, J. (2017). Introductory Chapter: Congruence of Personal and Organizational Values-How to Deal with? In Congruence of Personal and Organizational Values. IntechOpen.

Vveinhardt, J., \& Gulbovaite, E. (2013). Comparative analysis of the researches on personal and organizational value congruence. Management of Organiz.Research, 67, 127-142.

Vveinhardt, J., \& Gulbovaite, E. (2014). Diagnostic Instruments for Value Congruence. Journal of Business Theory and Practice, 2(2), 126-151.

Vveinhardt, J., \& Gulbovaite, E. (2017a). Models of Congruence of Personal and Organizational Values: How Many Points of Contact are There Between Science and Practice? Journal of Business Ethics, 145 (1), 111-131.

Vveinhardt, J., \& Gulbovaite, E. (2017b). Congruence of Personal and Organizational Values: Moving Beyond Practice. Montenegrin Journal of Economics, 13(2), 81-92.

Westerman, J.W. \& Cyr, L.A. (2004). An integrative analysis of person-organization fit theories. International Journal of Selection and Assessment, 12 (3), 252-261.

Westwood, R.I., \& Posner, B. Z. (1997). Managerial Values Across Cultures: Australia, Hong Kong and the United States. Asia Pacific Journal of Management, 14(1), 31-66.

Wollack, S., Goodale, J., Wijting, J., Smith, P. \& Feishman, E.A. (1971). Development of the survey of work values. Journal of Applied Psychology, 55(4), 331-338. 